\title{
Estímulo para Paulo Endo ${ }^{1}$
}

Os campos de concentração, tornando anônima a própria morte e tornando impossível saber se um prisioneiro está vivo ou morto, roubaram da morte o significado do desfecho de uma vida realizada. Em certo sentido, roubaram a própria morte do indivíduo, provando que, doravante, nada - nem a morte - lhe pertencia e que ele não pertencia a ninguém. A morte apenas selava o fato de que ele jamais havia existido (Hanna Arendt)

São Paulo é uma cidade de pessoas invisíveis: carroceiros, moradores de rua, crianças e adolescentes em situação de pobreza nos semáforos. Destituídas do reconhecimento de sua existência humana e de sua alteridade, despertam indiferença.

Muitas vezes eles resistem para existir, como aponta o padre Júlio Lancelotti, pároco da capela de São Miguel Arcanjo e vigário episcopal para o povo da rua da arquidiocese de São Paulo, citado por você. Muitas vezes resistem pela violência. E quando se tornam visíveis para o outro, quando afirmam a sua existência, a indiferença torna-se ódio.

No Brasil mata-se mais do que em lugares que se encontram em franca situação de conflito armado. Certos países europeus consideram o inimigo o refugiado, o imigrante, o asilado. No Brasil o inimigo é o jovem desempregado, de baixa renda e baixa escolaridade. São eles o alvo privilegiado dos homicídios e da violência praticada pelo Estado.

O relatório do Atlas da Violência 2018 (IPEA) aponta que a violência contra a mulher é efetivada por agressores do núcleo doméstico, e os casos de estupro subiram 51\%, tendo como vítimas menores de onze anos. Aponta também uma taxa de homicídios de pessoas entre quinze e dezenove anos de idade, taxa alarmante. É o dobro da média nacional e mais de seis vezes a taxa global de homicídios de jovens, sendo que 94\% dos casos são do sexo masculino.

Como entender a omissão da população civil em relação à violência do Estado nas ruas, principalmente nas periferias? Como a Psicanálise pode nos ajudar a entender esta situação?

\footnotetext{
${ }^{1}$ Este estímulo foi preparado pela comissão organizadora do I Simpósio Bienal "O mesmo, o outro: Psicanálise em movimento" da Sociedade Brasileira de Psicanálise de São Paulo, para o "Fórum Violência e alteridade".
} 